\title{
Perception of adult men on their preventive practices and health support networks
}

\author{
Percepção de homens adultos sobre suas práticas preventivas e redes de apoio em saúde \\ Percepción de hombres adultos acerca de sus prácticas preventivas y redes de apoyo en \\ salud
}

\author{
Guilherme Oliveira de Arruda ${ }^{1}$, Mayckel da Silva Barreto ${ }^{2}$, Sonia Silva Marcon ${ }^{1}$
}

\begin{abstract}
Objectives: to know the preventive practices adopted by adult men in daily life and to identify health support networks. Methods: a descriptive qualitative study, made during the months of November and December 2012, at two emergency units, along with 32 men aged between 20 and 59 years. Data were collected through semi-structured interviews and subjected to content analysis with thematic modality. Results: men highlighted different preventive practices such as sanitizing hands, eating properly, having screening tests, avoiding psychoactive substance abuse, using personal protective equipment at work and condoms during sex. Most of the participants had nuclear family and its members were their primary support network regarding the health-disease process. Conclusion: it is for health team members to try to leverage the adoption of preventive practices by adult men from the support networks they consider significant.
\end{abstract}

Descriptors: Men's Health; Adult; Disease Prevention; Social Support; Health Services.

Objetivos: conhecer as práticas preventivas adotadas por homens adultos no cotidiano e identificar suas redes de apoio em saúde. Métodos: estudo descritivo de natureza qualitativa, realizado durante os meses de novembro e dezembro de 2012, em duas unidades emergenciais, junto a 32 homens com idade entre 20 e 59 anos. Dados coletados mediante entrevista semiestruturada e submetidos à análise de conteúdo, modalidade temática. Resultados: os homens destacaram diferentes práticas preventivas como: higienizar as mãos, alimentar-se adequadamente, realizar exames de rastreamento, evitar uso de substâncias psicoativas, utilizar equipamentos de proteção individual no trabalho e preservativos durante as relações sexuais. A maioria dos partícipes tinha família do tipo nuclear, sendo seus membros sua principal rede de apoio em relação ao processo saúde-doença. Conclusão: cabe aos integrantes da equipe de saúde tentar potencializar a adoção das práticas preventivas por homens adultos a partir das redes de apoio que eles considerem significativas.

Descritores: Saúde do Homem; Adulto; Prevenção de Doenças; Apoio Social; Serviços de Saúde.

Objetivos: conocer las prácticas preventivas de hombres adultos en la vida diaria e identificar sus redes de apoyo de salud. Métodos: estudio cualitativo, descriptivo, realizado entre noviembre y diciembre de 2012, en dos unidades de emergencia, con 32 hombres entre 20 y 59 años. Los datos fueron recolectados a través de entrevistas semiestructuradas y sometidos a análisis de contenido, modalidad temática. Resultados: los hombres destacaron diferentes prácticas preventivas, como higiene de las manos, comer correctamente, realice pruebas de detección, prevenir el abuso de sustancias, utilizar equipo de protección personal en el trabajo y condones durante las relaciones sexuales. La mayoría de los participantes tenía familia nuclear, siendo sus miembros su principal red de apoyo en relación al proceso salud-enfermedad. Conclusión: compete a los miembros del equipo de salud intentar potencializar a adopción de prácticas preventivas por hombres adultos a partir de las redes de apoyo que les consideran significativas.

Descriptores: Salud del Hombre; Adulto; Prevención de Enfermedades; Apoyo Social; Servicios de Salud.

\footnotetext{
${ }^{1}$ Universidade Estadual de Maringá. Maringá, PR, Brazil.

${ }^{2}$ Fundação Faculdade de Filosofia, Ciências e Letras de Mandaguari. Mandaguari, PR, Brazil.

Corresponding author: Guilherme Oliveira de Arruda

Avenida Colombo, 5.790, CEP: 87020-900 - Maringá, PR, Brazil. E-mail: enfgoa@gmail.com
} 


\section{Introduction}

In Brazil, the relationship of men with health practices is increasingly inserted in the scientific and academic debates, through studies that focus primarily on the specific profile of morbidity and mortality and the influence of public policies ${ }^{(1)}$, the needs concerning health of adult men ${ }^{(2)}$, behavior and health care of the male population ${ }^{(3)}$ and the standards of use of health services ${ }^{(4)}$. However, the scarcity of studies that propose the investigation of preventive health practices is perceived, as well as the role of support networks in activities related to health-disease process of adult men.

However, to discuss health prevention, it is necessary to consider the steps of elaboration of prevention that, to a certain extent, follow the model of the natural history of the disease ${ }^{(5)}$, that is, preventive action involves two stages: a pre-pathogenic one, consisting of actions for the promotion and health protection; and another pathogenic one involving diagnosis, early treatment and rehabilitation, because the disease is already present and the objective is to limit the damage.

In the quest for well-being, social support networks are formed, which can be defined as the set of relations which the subject establishes and considers significant in health situations and periods of illnesses, acute or chronic. The importance of supporting networks in maintaining the health of the subject, in leveraging early recovery after the onset of the disease and even in a better adaptation and the experience with a chronic illness is recognized ${ }^{(6-7)}$.

Thus, it is believed that the adoption of preventive practices by men can be reinforced by support networks, favoring the socialization of men's needs, which contradicts the reductions imposed by the medication and the health-disease model of biomedical nature, thus enabling, to reduce personal barriers able to limit health care. Facing that, this study was guided by the following question: "How are the practices of health promotion by adult men and how are they related to their support networks?". Facing such question, this study aimed at knowing the preventive practices by adult men in daily life and identifying their health support networks.

\section{Method}

It is a descriptive and exploratory study, of qualitative nature, made in two health services: the first-aid post of the county of Mandaguari, PR, and the first-aid post of the Hospital Universitário Regional (the county hospital of Maringá, PR, Brazil). These services were listed based on the profile of assistance to the male population, once in those services, there is a great demand by adult men, mainly due to work and traffic accidents. The interviewees were 32 men assisted at the health service during the data collection period, having only one criterion of inclusion, aged between 20 and 59 years. It was considered criterion of exclusion not presenting clinical, physical and/or mental conditions to participate in the interview, such as severe trauma, orotracheal intubation or psychotic break.

Data were collected in November and December 2012 through semi-structured interviews, using a script consisted of two parts. The first contained questions which aimed at characterizing the subject (age, marital status, occupation, number of children and origin) and the second presented issues investigating the adoption of preventive practices and health promotion, the elaboration of social support networks facing the disease and the reasons which lead adult men to discuss health promotion.

The interviews, lasting an average of 30 minutes, were held at the emergency units, in a private room, which guaranteed the privacy of the interviewee. The content captured through the guiding questions was recorded and transcript fully, with further editing of 
the statements, whose aim was to eliminate grammar and verb agreement or vices of the language, allowing greater clarity and better interpretation of verbalized content.

Then the transcript material was submitted to content analysis with thematic modality, which attributes importance to the words and their meanings through the pursuit of different realities embedded in the messages ${ }^{(8)}$. Although there are no strict rules for content analysis, the results were given a logic sequence with the following systematic procedures: initial organization of material, superficial reading, a deeper reading with the emerging of indicators, data encoding and finally categorization which brought together the messages in three thematic categories, namely: health prevention by adult men: motivation and practices, opportunities and conversation demands on the health of men's daily lives and configuration of male support network for health care.

This study was made according to the principles expressed in Resolution 466/12 of the National Health Council, with the approval of the research project by the Permanent Committee of Ethics in Research of Human Beings of the Universidade Federal de Maringa (Legal opinion No. 132 578). The Inform Consent form was signed in two identical copies, one of which was delivered to the interviewee. To ensure the anonymity of the participants they were identified by their profession followed by their age.

\section{Results}

The study included 32 men with ages ranging from 20 to 59 years (average of 36.1 years). Most of them were formally or informally in the labor market and lived with the family of nuclear type (partner and children). The average age of married men was 36.6 years and 28.7 years of single men. It is highlighted that 22 men had at least one child (average of 3.1 children) and one of them had 12 children.

\section{Health prevention for adult men: motivation and practices}

In this category the statements of the interviewees, according to their personal views on health prevention, revealed different habits that they believed to be a promoting behavior or a maintainer of good health. It can be noticed that the main factors involved in the genesis of this preventive behavior among men, were: age, family history of chronic disease and personal history of worrying symptom. $M y$ family is diabetic, then once a year I have a blood exam, taking care of it, so that if it appears, I begin to treat (Machine operator, 44). From time to time I felt like twinges in my breast, then I tried to have the treadmill exam. Whenever I can I ask for medical examinations (Shop assistant, 38). The doctor asks some exams, fifty years are already there and I have to do some exams, such as prostate which I've already done (Retired 2, 51).

Among the preventive activities the following ones were highlighted: healthy eating, physical activity and decrease or stop the use of alcohol and tobacco. My action is to watch out for my food, I eat at the right time, the right food, without much exaggeration, this is my way to prevent disease (Trucker, 24). Only for the reason of not drinking, not smoking too much, I'm already contributing almost 100\%, practicing sport I feel happy to do (Security guard/Sailsman, 29). To start with, I drank a lot, but I do not anymore. Lost nights of sleep when I was drinking, I quit 14 years ago (Bricklayer, 43).

Among the various health prevention methods reported by men, the following issues were highlighted in their statements: the need of the examination of the prostate, due to the age of 40 years, which is reinforced by the guidance of health professionals; to maintain proper eating habits; and also to prevent the abuse of psychoactive substances or even the initiative to stop their use. The non-use of alcohol and tobacco is motivated by the fact that men recognize the negative implications of these habits on health and the difficulty increased for the recovery of the body 
facing serious diseases. Aversion to vices also comes from the experience of adverse situations lived by people close to them. I have some friends who have suffered accidents, who have already been hospitalized in a intensive care unit. There they said that, because of the cigarette, their picture was more problematic to be healed, even because of the alcohol, so I think the cigarette and drink harm enough (Electronics technician, 28).

The employment relationship is another factor that appears to play an important role in the adoption of preventive health activities, once it emerges as an opportunity for adult men to have investigative exams, even for occupational requirements. I have exam of blood, prostate, feces every year, because in the sector I work those exams are required. The doctor assists us every year (Pig farmer, 53). I take prevention action, yes, as I work in an area that can be harmful to my health and I try to use the safety equipment that the company provides (Furniture worker, 29). At the firm I worked for they provided flu vaccine, but after I left I buy it at the drugstore, so I think it's a form of prevention (Carpenter, 29).

An interesting finding which deserves highlighting was the fact that some men make reference to hand washing as a one of the key practices for health practices. So, they show worry inserting in they daily activities a simple sanitation practice in order to avoid contagious diseases. I get home and wash my hands well. If someone has the flu I don't even get close (Hairdresser, 32). I always wash my hands not to have them dirty (Welder, 20).

The use of condoms during sexual intercourse was also emphasized by some men, especially by the younger ones. The concern with the selection of sexual partners and the awareness of the existence of the risk of contamination proved to be linked to the use of condoms. The only preventive method we use is the condom, not the others (Glazier, 24). I use a condom in a sex relation, I go to the gym, I think with this I'm already preventing (Snack vendor, 24). I always use condoms, avoiding diseases and I have to know who I'm going out with, because nowadays it is difficult (Electrician, 40).

Moreover, shame can be an obstacle for some men to talk openly on preventive practices in health. The following statement reveals how much the youth, despite denying, showed to be embarrassed by the presence of his mother, so he did not report any more details on preventive practices that he usually follows in his daily life. Mother asks: want me to leave so you can to talk to him? No, I have nothing to hide (Showing embarrassment). I have health prevention, I do so (Administrative assistant, 21).

The facilities or difficulties in handling such issues can be based on the habit to talk or not about health, to express opinions, questions and needs in health and in this sense, the environment in which man is inserted or the occasions in which he is, can favor or not the development of this habit.

\section{Opportunities and demands of conversation on health in men's daily life}

Some men reported that they have the habit of talking about health, especially at home and with subjects who are part of their personal lives. Based on their statements, it is observed that the theme health is, in a way, within the daily conversation of men, whether in situations where there is a chronic health condition involved or not. I usually talk a lot about health with the people at home, my friends and neighbors (Retired 1,59). I talk to my children, always talk to them, not to do anything that harms health. I am so because I have always talked and preserved my health (Waiter 1, 59).

Different subjects participate in conversations which are present in the daily lives of these adult men, and this allows them to exchange knowledge about the theme health. In this scenario, they have a prominent role in the relation and/or concerns with their wives, children and grandchildren. It is highlighted that it was possible to perceive the presence of women in the dialogue involving health issues. I talk about health at home, between my wife and I because I have three grandchildren, of course you're going to worry about the grandchildren (Pig farmer, 53). At home we always talk about health, because I live with my mother. My sister is always at home, my brother, my niece and my daughter, then we always end up talking about health, but it is more talk about sex, 
because of the kids and all, clarify things on the use of condoms, how to take care (Waiter 2, 28). My wife and I talk at home when she's not ok, but in the street it is difficult. Only with my wife and with my children. I have a daughter who is already a teenager and so we talk a lot (Metallurgical worker, 37).

The trust of man in older people for believing in the experience they have is also perceived, providing answers to male expectations regarding their health. I always talk about health with the elderly, asking how it is, what it is for, why this is happening, talking is good (Bricklayer, 37).

In another case, it is clear that man finds security in dealing with health issues only with the doctor, reinforcing the ideal of confidence in the work of this professional. In these cases, it is possible that the difficulty in dealing with the health theme with friends or family arises from the fear and embarrassment that this may entail. With friends or family it is very difficult to talk about health stuff, we always have other issues, but we don't even mention health. Only with my doctor (Production assistant, 38).

It was found that the venues or occasions in which men feel comfortable to deal with questions related to health are diverse, though scarce, even for those who mentioned talking openly on the subject. These opportunities involved the workplace and the health service, when in situations of illness or health education activities. And on these occasions, the topics covered in the talks were varied, but always related to male behavior. Usually when I see that I'm kind of bad, I look for my boss and talk to him (Electronics technician, 28). It is very difficult to talk about health or disease, only when the thing is bad. It is usually there with the work people, with my father or my mother (Tractor driver, 28). It is very difficult to talk about health (Tiler, 34). The lectures on health, sex, fight, how to behave at home are good to talk (construction Servant 2, 39). I discuss this issue very little (health), sometimes with my own clients, because one comes and says, "Oh I have a problem" (Hairdresser, 29).

There are cases in which the invisibility of health theme in male dialogues is evident; it is suppressed by other issues that concern the daily tasks considered more important for these men. We usually remember health when we get sick or feel pain, something like that, but otherwise it's hard to remember health (Electronics technician, 28). You get involved with the work, then you talk very little (Security guard/sailsman,29). I do not get to talk, sometimes my wife asks, tells me to go to the doctor, she sets an appointment, everything is very much in a rush, but that's it, talking about health, no (Bricklayer, 43).

In this category it was possible to notice that some men talk about health in different places and about different topics, but in many cases, they still feel ashamed, they report that there is no available time to discuss health or believe they have no need to talk about their own health.

\section{Configuration of male support network for health care}

Amid the conversations, adult men build their support networks and health support with different settings and interests. For some, the support network basically consists of subjects with whom they are in touch daily, among them the partner is highlighted, who has an important role in health care, more specifically helping to remind the use of drugs or the day of the appointments. Although my family is large, my wife is the one who most helps me on the disease (Security guard/ salesman, 29). My wife always reminds me to take the hyper pressure medicine or the day to go to health unit, she is always by my side (Retired 2, 51).

At times, besides the partner, the mother and the sister are also supporting network for adult men. They are highlighted by their experience and will to offer help. The first option is my mother. I am married, but I kind of like to ask my wife, then I ask for help to my mother, who knows more (Mechanic, 26). In the family I have a sister who always supports me in health, when I need when I am ill she always supports me (Production assistant, 38).

In some cases, men pursuit the support of people who are part of their circle of friends and who are health professionals, providing easier access to diagnosis exam or to the informal prescription of 
medicine. Besides getting the medicine, they see in that support the opportunity of not having to directly seek the health service. My daughter-in-law works at a health unit and her aunt works at the health department that's why I get it. Like this ultrasonography that I will undergo next Thursday (Pig farmer, 53). They are usually friends of my wife who work at the health unit. Sometimes they force the result of a specialized exam, then it is easier (Electronic assistant, 38). I more often see my brother who is a doctor, and then I see with him some medicine he can give me, so I do not need to go the hospital or health unit (Glazier, 24).

There are also those who choose to go first to the drugstore in situations of disease considered light and in case more intensive care is needed, the drugstore employees themselves indicate the emergency health service. I try to go to the drugstore we already know for many years, but always in small cases, single cases they can already solve. In more complex cases they (drugstore) tell us to come here (Emergency Department) (Hairdresser, 29).

From these statements, the strong presence of feelings was identified such as objectivity and independence, concerning the search of adult men for health care. A contradictory scenario is also observed in which, despite knowing the context male vulnerability, even so, men do not seem to bother about the formal care provided at the Basic Units of Health and Hospitals, reinforcing the existence of the feeling of invulnerability which follows the male imagination.

Unlike other men who allow themselves to receive help from close people, Waiter 1 and Polisher showed not recognizing the importance of their support network in health promotion and adoption of preventive practices. Sometimes the family tells us to have a check up, and because we are stubborn we don't go, and that is why the study showed that more men die than women because men are stubborn, they don't want to go to the health unit, they do not want to have a prostate exam (Waiter 1,59). My mother always tells me to have a check up, but I do not listen. A young man does not care, he only cares for worldly things, nothing else (Polisher, 29).
The statements presented in this category can infer that the main support network for men at the time of illness is the family, and they turn first to them, but some reported other sources of support as fellow workers, drugstores and the health unit itself. However, it is necessary to point out that some men reported receiving help and guidance related to the health from their families, not always valuing or following this guidance.

\section{Discussion}

According to the results found it is observed that the different health prevention measures adopted by men are related to the concepts reproduced on the process of the cause of the disease, for example, the influence of unhealthy diet, physical inactivity, harmful consumption of alcohol and tobacco, the risk of contamination by sexually transmitted disease and carelessness in a situation of a disease already established. For men, the health care results in maintaining a productive body free of diseases, which may expose the male body to situations of restriction and to the exposition of their limitations and weaknesses ${ }^{(9)}$.

Along the same line of thinking, the preservation of good physiological conditions permeates the male prevention practices, since the demand for the welfare and maintaining a capable body may be related to the need to work and not to lose their position at the workplace, as already reported in the literature $^{(10)}$. Moreover, as found in this study, men had the opportunity to get in touch with prevention practices in health from their occupational settings, being presented as experiences of approximation of this universe which shows to be so linked to female sex.

Facing habits marked by routine exams to be made in the company, immunization and use of safety 
equipment, one should emphasize the importance of initiatives related to health in the work environment for context of male health and if they do not immediately interfere in the profile of morbidity and mortality characterized by excess mortality at all ages, high rates of hospital morbidity due to cardiovascular and cerebrovascular diseases and external causes ${ }^{(1)}$, they show to be an important set of principles for changes in the male way of exercising the care of himself and in the image of the man facing the cultural scenario.

One should strengthen the relevance of educational interventions on health prevention, from simple hand sanitation, which is essential practice in the professional scope, to the use of condoms as the primary strategy for preventing sexually transmitted diseases. With that, it will be possible to make men recognize and value the preventive practices in general, seeing that the withdrawal and even the estrangement concerning such practices, conditions men to curative care, allies included, to the little demand for health services, which hinders the implementation of policies and specific programs ${ }^{(11)}$.

A study made with 25 male workers aged 18 to 49 , showed that educational interventions had significant effect on the level of knowledge of the subjects, particularly on factors related to high blood pressure, diabetes mellitus, prostate cancer and cerebral vascular accident ${ }^{(12)}$. It is understood that health education strategies for the main needs and demands of men can contribute to the empowerment of these, having the objective to improve the health profile from the progress of lifestyles.

It was noticed that the habit of using condoms during sex came alone as one of the main forms of health prevention recognized by adult men, a fact possibly associated to increased media coverage of preventive measures for Sexually Transmitted Diseases and AIDS.
However, even if there is this greater recognition on the use of condoms by men, the taboos still exist and permeate the domain of male sexuality. The shame in dealing with issues related to sexuality permeates the relation of men with health professionals as it makes him subject to handle delicate boundaries, that is, thinking about illicit and private boundary and when their behaviors are approved or disapproved ${ }^{(2)}$; in this environment, common practices among young men as not using condoms, which is increasing from the 1990s and has been called "condom fatigue" or the belief that the choice of the younger partner alone can reduce risks of acquiring diseases, makes man a vulnerable subject ${ }^{(13)}$.

Male statements about health prevention refer to concepts already well known concerning common sense, such as the purpose of avoiding the disease, the possibility to feel comfortable and the positive implications on everyday life. Such views were also observed in a study of 46 women users of the Health County Centers, however, with strong influence of pleasure and will power to prevent from those diseases and the great interest in information and guidance on health ${ }^{(14)}$. Thus, the motivation is identified for preventively taking care of himself as an aspect to be worked with adult men, considering the barriers in triggering practices of prevention and health promotion, especially influenced by the social and cultural construction of gender, based on daily experiences which do not favor the male care ${ }^{(10)}$.

Therefore, the strengthening of man-health relation can favor the adoption of preventive practices by them, especially when a dialogical relationship between men and their support networks is established through the habit of talking about health. The ability to express their needs concerning health, to highlight the health discussion, to question and to learn more allows men to free themselves from a dependence and an alleged male objectivity that 
prevent them to seek support for health ${ }^{(10)}$.

For such, besides the workplace, men would have in their own home and with people with whom they live, the opportunities to socialize on the health topic. In this context, the presence of women in the care of men's health reinforces the dependence that they also have, but who are reluctant to accept. Although the efforts to ensure the prevention or face the illness imply in a series of conflicts and even social and family rearrangements and derangements, there is an ambiguity in the relations of gender in the scope of care, characterized by complicity or distance between men and women ${ }^{(15)}$.

Regarding sexuality, it is understood that sex is closely linked to the process of construction and gender socialization, so that the man sometimes is shown irritable and even aggressive with the woman when it is not reciprocated sexually or when he cannot, for example, sexually relate with her due to illness ${ }^{(15)}$. Facing the results of this study, it is understood that talking about sexuality motivated by the presence of adolescents and also of women in the household lead men to think that the exercise of sexuality should not be conceived or linked only to the need of man "having a woman" and to establish sexual relationships themselves. He also demonstrates his sexuality through his statements in which he socializes experiences, knowledge and doubts, and learn from the uniqueness of each social gathering, which ultimately shapes his identity of gender ${ }^{(15)}$.

Again, it is also interesting not to reduce such issue to specific diseases of man in this domain (erectile dysfunction, infertility, prostate diseases) but enhances the look on the practices of prevention and lessen the strangeness that constrain men in these cases $^{(16)}$. For such, the existence of a social support network plays an important role in the daily lives of some men.

This is because, it was observed that the relationships established by men are given mainly to people with whom they have close contact, and the family members stand out in this context. If necessary, having someone to seek support promotes relief and safety for man and using communication makes him feel comfortable and empowered, in situations of suffering or not ${ }^{(6)}$. Facing that, talking represents a communicative process, synonymous of help, attention, sharing and reinvigoration of positive relationships for health ${ }^{(7)}$, and to confirm that the socialization of this issue in many occasions, combats invisibility and male passivity facing health.

Consequently, health professionals should be alert to the identification of this support network and take advantage of different opportunities to establish contact with men, thus reinforcing the importance of healthy relationships and establishing new contacts for health ${ }^{(6)}$. However, when the subject does not build healthy relations, it is also up to the health professional to intervene so that changes in this direction occur.

In the present study, it was evident that the use of drugs permeated both the good and the bad relations of the support network. The network performance is positive when the man takes advantage of complicity with his partner to address and prevent non-adhesion to the prescribed medication for a chronic disease. However, in the event that man uses self-medication to deal with problems that he judges likely to be solved at home, eliminating the need to search for health service, proves to be a gap in men's self-care and still a challenge for the health teams, once it can predispose to inappropriate medication use $\mathrm{e}^{(17)}$.

Amid the tactics developed to ensure access to medicine, it is necessary to identify the mistakes caused in everyday life, considering that the practices of medication should not be deprived of following the prescribed dose by a health professional who is prepared for this and needs to know the role of the subject on his self-care ${ }^{(18)}$. Moreover, the replacement 
of the health service by the inadvertent use of medication as a practice to avoid a possible "loss of time" in solving the problem, only contributes for a picture already shown in the literature, in which man postpones the search for professional support sometimes due to the delay in assistance ${ }^{(19)}$, seeking it in advanced stages of his health problem ${ }^{(20)}$. Failure in recognizing the importance of supporting elements in their lives also enhances this pattern of use of health services reinforces the feeling of invulnerability and makes the maintenance of health difficult.

In this regard, the importance of the search to know how the adult man takes care of his health is emphasized because it involves not only reports on habits and causes that motivated the demand for emergency care services, often in extreme situations, but also statements which show how man thinks concerning his behavior, which relations he establishes and which are his initiatives to keep good health, especially his support networks.

\section{Final Considerations}

In this study, different practices of health prevention used by adult men were found, according to their ideas and their experiences in everyday life. At first they may seem simple, with little representation for the unfavorable profile of health commonly observed in different contexts, however, they indicate potential changes in the representations that surround the social identity of those men, once it agrees with rigid representations on the male behavior in health and, at the same time, relativises them.

Knowing that men are able to talk and even become interested in sharing issues related to health, they deconstruct restrictions which attain to the women the role of their dialogue with men. Thus it makes men come closer to this vital domain, which does not contemplate their presence satisfactorily. The non-perception of health by man, as a discourse that needs to be incorporated into their daily lives, predetermines the invisibility of the subject especially to the eyes of health professionals, that is, the lack of interest for conversation predisposes the lack of interest for the demand.

In this regard, this research provides collaboration once it investigated and showed who the adult man recognizes as a support network concerning health. Furthermore, it emphasizes the importance of educational interventions and points out some issues that permeate or not the search for support by men. It is highlighted that, as important as the search for relationships of support in times of illness, maintaining positive relationships when healthy, allows men to cultivate prevention and protection against disease.

It is therefore concluded that the health professional can improve the comprehensive health care of man, through the enhanced look which goes beyond the subject and contemplates the opportunity of positive relationship in different contexts that permeate the initiative of prevention in health.

\section{Collaborations}

Arruda GO contributed for the conception of the work, data collection, analysis, data interpretation, writing of the article and final approval of the version to be published. Barreto MS contributed for the conception of the work, analysis, data interpretation, writing of the article and final approval of the version to be published. Marcon SS contributed for the conception of the work, analysis, data interpretation, writing of the article and final approval of the version to be published. 


\section{References}

1. Schwarz E, Gomes R, Couto MT, Moura EC, Carvalho SA, Silva SFC. Política de saúde do homem. Rev Saúde Pública. 2012; 46(Supl.):108-16.

2. Schraiber LB, Figueiredo WS, Gomes R, Couto MT, Pinheiro TF, Machin R, et al. Necessidades de saúde e masculinidades: atenção primária no cuidado aos homens. Cad Saúde Pública. 2010; 26(5):961-70.

3. Knauth DR, Couto MT, Figueiredo WS. A visão dos profissionais sobre a presença e as demandas dos homens nos serviços de saúde: perspectivas para a análise da implantação da Política Nacional de Atenção Integral à Saúde do Homem. Ciênc Saúde Coletiva. 2012; 17(10):2617-26.

4. Borges LM, Seidl EMF. Percepções e comportamentos de cuidados com a saúde entre homens idosos. Psic Ciênc Prof. 2012; 32(1):6681.

5. Leavell S, Clarck EG. Medicina preventiva. São Paulo: McGraw-Hill; 1976.

6. Feijó AM, Schwartz E, Muniz RM, Santos BP, Viegas AC, Lima LM. As inter-relações da rede social do homem com câncer na perspectiva bioecológica: contribuições para a enfermagem. Texto Contexto Enferm. 2012; 21(4):783-91.

7. Di Primio AO, Schwartz E, Bielemann VLM, Burille A, Zillmer JGV, Feijó AM. Rede social e vínculos apoiadores das famílias de crianças com câncer. Texto Contexto Enferm. 2010; 19(2):334-42.

8. Bardin L. Análise de Conteúdo. São Paulo: Edições 70; 2011.

9. Martins AM, Gazzinelli AP, Almeida SSL, Modena CM. Concepções de psicólogos sobre o adoecimento de homens com câncer. Psicol Teor Prát. 2012; 14(2):74-87.
10. Figueiredo WS, Schraiber LB. Concepções de gênero de homens usuários e profissionais de saúde de atenção primária e os possíveis impactos na saúde da população masculina, São Paulo, Brasil. Ciênc Saúde Coletiva. 2011; 16(Supl. 1):935-44.

11. Ramalho MNA, Albuquerque AM, Maia JKF, Pinto MB, Santos NCCB. Dificuldades na implantação da política nacional de atenção integral à saúde do homem. Cienc Cuid Saude. 2012; 13(4):642-9.

12. Leite DF, Ferreira IMG, Souza MS, Nunes VS, Castro PR. A influência de um programa de educação na saúde do homem. Mundo Saúde. 2010; 34(1):506.

13. Pinheiro TF, Calazans GJ, Ayres JRCM. Uso de camisinha no Brasil: um olhar sobre a produção acadêmica acerca da prevenção de HIV/Aids (2007-2011). Temas Psicol. 2013; 21(3):815-36.

14. Marques SC, Tyrrell MAR, Oliveira DC. As práticas educativas na prevenção do HIV/Aids das usuárias da rebe básica de serviços de saúde do município do Rio de Janeiro. REME Rev Min Enferm. 2013; 17(3):538-46.

15. Thomé EGR, Meyer DEE. Mulheres cuidadoras de homens com doença renal crônica: uma abordagem cultural. Texto Contexto Enferm. 2011; 20(3):503-11.

16. Pinheiro TF, Couto MT. Homens e camisinha: possibilidades e limites na construção da Saúde do Homem. BIS Bolet Instit Saúde. 2012; 14(1):4955 .

17. Cunha KOA, Renovato RD, Descovi MS, Dal Vesco JR, Silva CA, Missio L, et al. Representations regarding the rational use of medications in family health strategy teams. Rev Esc Enferm USP. 2012; 46(6):1431-7.

18. Arruda GO, Renovato RD. Uso de medicamentos em transplantados renais: práticas de medicação e representações. Rev Gaúcha Enferm. 2012; 33(4):157-64. 
19. Cabacinha ROM, Cabacinha CD, Moraes DS, Barbosa HÁ, Pinho L. Social demographic aspects and self-referred health conditions of men attending a health care unit. Rev Rene. 2014; 15(5):804-11.
20. Couto MT, Pinheiro TF, Valença O, Machin R, Silva GSN, Gomes R, et al. O homem na atenção primária a saúde: discutindo invisibilidade a partir da perspectiva de gênero. Interface Comun Saúde Educ. 2010; 14(33):257-70. 